\title{
The rule: (There is no crime and no punishment except by the text) of a jurisprudential study through the Qur'an and Sunnah
}

\author{
Dr. Rafid Hasan Majeed \\ Department of Islamic Education, College of Basic Education, University of Misan, Iraq. Email: rafedalali71@gmail.com
}

\begin{abstract}
Islamic Sharia is considered a complete and comprehensive law for all the requirements of life. The Holy Qur'an is the first fundamentals of Sharia, indicating its provisions and supported by the noble Sunnah, and it is the second source of Islamic law. Its sources, and the significance of the Holy Qur'an in its entirety, dedicated to its year and limitation to the absolute. It has a legal text, and the act or omission is not considered a crime unless this act is forbidden or imposed by divine legislation. This is because the legislator has to state what he is being punished for, and this meaning is mentioned in the rule: ((There is no crime or punishment without a text))

The main question in this paper is how did Islamic law deal with this rule?

And the sub-questions: What is the meaning of the rule and its vocabulary? What are its evidence and its most important applications?
\end{abstract}

Keywords:

The rule in permissible - the rooting of the rule ( No crime and no punishment without text - Applications of the rule (no crime and no punishment without text)

Article Received: 18 October 2020, Revised: 3 November 2020, Accepted: 24 December 2020

\section{In the name of of Allah the Merciful}

\section{Introduction}

The Almighty said: (We have not given us a messenger). [1], and blessings and peace be upon the last of the prophets and messengers Mustafa Muhammad, and his chosen divine family.

\section{Or published}

Islamic law is a complete and comprehensive condition for all life, so he says: Today we complete your religion and I have perfected my grace over you and chose Islam for you ([2], and the Almighty said: "We sent down a book to you that clarifies everything, guidance, mercy, and good news for Muslims." [3] The Holy Quran is the first the fundamentals of Sharia, an indication of its provisions, and the honorable Sunnah upheld it, which is the second source. Of the sources of Sharia, and an indication of the Holy Qur'an in full and dedicated to its year and limited to the absolute, and Sharia does not leave a reality unless it has a legal text, and the act or abandonment is not. Unless this act is forbidden or forbidden by divine legislation, because the legislator has to state what he is punished for, and this meaning is expressed in the rule: ((There is no crime and no punishment except with a text)).

The main question in this paper is how Islamic law dealt with this rule?

And the sub-questions: What is the meaning of the rule and its vocabulary? What are its significance and its most important applications? This research included three demands, the first of which was in explaining the terminology of al-Qaeda, the second: in rooting the rule from legal evidence and principles, and the third: in the most important applications. Add to the introduction and conclusion.

The first requirement :In a statement of base terminology(( There is no crime and no punishment except with a text))

Since the perception of something is a condition for judgment, it is important to get acquainted with the concept of base terminology. Therefore, it was necessary to define it, so we spoke about it in several branches:

The first branch :the concept of al-Qaeda in language and idiom 


\section{First the base language}

The basis [4], compiled on the rules: the foundations of a thing and its arrival (the Almighty) While the rules of Ibrahim al-Bat were raised ([5]. According to al-Arab: ((rules: basically, the rules) from the house was. Al-Zajaj said: The construction is deliberate .. The rules of haddaj: four logs at the bottom of the ride, the sticks of the bridegroom in. Abu Obeid said: The rules of the cloud against which the objectionable in the horizons of Paradise is similar to the rules of construction)) [6]. And raising the provisions in the previous verse means building on them [7]. From the previous definitions that I mentioned, it becomes clear that the meaning closest to the rule is the first meaning, which is the basis. Because the provisions are based on them, and the wall is built on the foundation.

\section{The second: the rule traditionally}

Some of them know him, Noha: ((The subject of the faculty applies to all fractions)) [8]. And the second of his definition: ((The whole issue is that it forcibly includes provisions for the details of its subject)) [9]. Third and its definition: ((It is given meanings: synonymous with origin, law, object, control, and intention. I knew that it is a comprehensive system that applies to all its parts when its provisions are determined from it)) [10]. Note on these definitions that they are consistent in meaning, although sometimes they have expressed the case, and other times in total order.

The second branch: the concept of crime in language and convention

\section{First: The meaning of the language crime}

The offense: in the sense of guilt - and the offender: the perpetrator, the culprit: the sinner [11] - and the acquisition of sins. I heard the Arabs say: So-and-so, and so is his family's crime, that is, their blasphemy. And they went out for the offense of his family, meaning that he would gain them [12] Explain the verse :) And God criminalizes you that people are tempting your truthfulness from the Sacred Mosque to disagree ([13] in this sense, that is, I do not do regardless of your earnings, for they consider them what is not permissible for you by Sharia
[14], The most common mischief is bad earning [15]

\section{Second: the crime convention}

Legal offenses and prohibitions that God commanded by Himself or discretionary [16], and this definition includes the crime that is committed by committing a forbidden act, and also includes the act that is done by refraining from doing the command, since the word includes the "legal prohibitions" involved. It was also known as: ((An act or abstention from the Sharia in forbidding and punishing it)) [17] and Abu Zahra (T.: 1394 AH) defined it: ((It is disobedience) what God commanded by virtue of the Sharia) [18]. The last definition is general so that it includes the crime punishable by the worldly ruler, as well as the acts that are punishable by the penalties of legal commission that constitute expiation for sins, in addition to the punishments that are postponed until the Day of Resurrection with our Lord. Realms [19].

\section{Section III: The concept of punishment language idiomatically}

\section{First :Punishment in language}

The word punishment is the noun of the verb "after," which is the punishment for sin, hardship, and difficulty. And it has been mentioned in language dictionaries: ((Punishment and punishment is a man's reward for what he did badly, and the name is the punishment, and his sin punishes him with punishment and punishment))) [20]. Ibn Faris (T. After something, it is his result, and the results of everything else.)) [21]

\section{Second: Punishment as a convention}

The sayings of the jurists differed in the same meaning in defining the punishment in conventional terms. I also learned that: ((The pain that afflicts a person deserves a felony)) [23]. Some contemporary scholars defined it as follows: ((The punishment is set in favor of the worshipers for disobeying the street order)) [24]. These definitions are close in meaning, although they differ in terms of terminology. Perhaps the first definition of Mawardi (d.: $450 \mathrm{AH}$ ) is the best of these definitions. Informing him of the prescribed penalty in exchange for committing prohibitions 
and abandoning duties. The punishment is, in fact, a crime set by God Almighty to deter people from leaving what is commanded and committing forbidden actions. Punishments in Islamic law are divided into specific and limited penalties, and non-ratified penalties, and the first is divided into three sections: the first section: border punishments, and includes border crimes, including: punishment for adultery, defamation of death, punishment for drinking, punishment for theft, spears of death, and punishment for slander. The second topic: Penalties for retribution and blood money, which are the penalties prescribed for crimes of self-assault and less. These are: the penalty for premeditated murder, the penalty for semi-intentional murder, the penalty for premeditated murder, and the punishment for intentional assault on someone other than oneself. The third topic: Penalties for atonement, namely: established penalties for some self-assault crimes The scholars are agreed that manslaughter is obligatory, and they differed as to whether it is obligatory and semi-intentional killing. The second punishments are not appreciated and are called discretionary punishments: They are punishments imposed on crimes that the street does not inflict in its discretion, so its appreciation remains with the guardian.

The fourth branch: the concept of text in language and convention

No: the language of the text: it has many connotations in the Arabic language, such as the Qasaa, the absolute, and the movement. Appointment and arrest. However, these different meanings are nothing but metaphors; the original meaning rises and emerges.

Ibn Manzur (d. $711 \mathrm{AH}$ ) says: ((The text: You set up something, the text of the hadith: He raised it, and wrote everything that was revealed ... and the original text is the ultimate. And the thing)) [25] And it says in Taj al-Arous: "The original text: raising you and showing something, it is from raising and appearing, and from it the stage ... something, and all of that is a borrowing from the text. Meaning lifting and appearing)) [26]

\section{Second, the text term of}

Al-Ghazali may compute the text with common definitions of scholars called in three ways: The first aspect: what Al-Shafi'i launched, as he called al-Zahir a text, and it applies to the language, and there is no objection to it. It is in the Sharia, and the text in the language means to appear. The second aspect: it is the most famous. Unless it is discussed with the possibility at all, neither near nor far, like the five, for example, because it is a text in its meaning that does not tolerate the six or the four and the rest of the preparation. The third aspect: the expression in a text that does not mention an acceptable possibility supported by the evidence [27]. And because the text has many meanings in different sciences, the phrase can be pronounced and used in it, as in the Arabic language, and the explicit word that carries only one meaning is pronounced and referred to with connotations in the fundamentals of jurisprudence. . From the book or the Sunnah, either explicitly or in deduction, and it matches the linguistic meaning [28].

The second requirement: rooting this rule from legal evidence

And search for it on branches

\section{The first branch: the rooting of the rule from the Holy Quran}

There are many verses from the Noble Qur'an which indicate the justice of God Almighty in his creation, and that he does not torture anyone until after he sends him a messenger to warn and warn him. So that there is no evidence for it, and the Almighty has explained this meaning in many verses, including:

1- The saying of God Almighty: (He tormented us) or until we send a messenger ([29], and this verse talks about that the torment of God cannot be inflicted upon a nation or group of them or even a person without that. It will be an argument and a statement of the messengers and prophets assigned to him (peace be upon them). God Almighty does not punish or punish anyone, before the controversy against him is completed, and before he clarifies his mandate, then at the beginning God places his orders and prohibitions on people, and if they abide by them and obey, 
happiness will reach them in this world and the hereafter, and if they disobey and disobey and do not abide by the commands of the Lord and prohibitions., Then you will be tormented, then it will lead to their destruction. Sheikh Al-Tusi (tel.: $460 \mathrm{AH}$ ): (And we said) He tormented us until we sent us bowing (it was reported by God that no one is punished for his sins, for him and to guide us to his behavior, cultivating him in arguments, you ause if you meet Reason 3 and you need to listen to the right, be sure to remove the command and uncertainty that is necessary for the server)) [30]. The narrator's investigator (d: 1209 AH) said: ((He tortured us until we sent a messenger, and he and his methods of permissibility of command and permissibility of action before resurrection, which is a phenomenon that is not hidden, and also after the dispatch of the messengers, because there is no doubt about their actions and their actions, and before the mission of the messengers was in order not to The assignment reached them, and there is no doubt that this matter, although there is no text in it, is present after the mission as well)) [31]. As we were tortured, we were sending a messenger. [32] The verse indicates that duty is not achieved until after the emergence of Sharia [33]. There is a discussion among the commentators about the type of torture intended here, and whether it is a kind of torment that occurs in this world or in the Hereafter, or is it a torment (eradication), i.e. general demolition. A torment like the flood of Noah, for example? [34]. and the author of Tafsir al-Bahr chose the first ocean, and said: ((The torment of exile in this verse is a punishment in this world and the hereafter, as evidenced by the words of the Almighty: (If we want to destroy a wealthy)). A village, then stick to it. [35] While others went to it. The meaning of torture in the verse, because the penalty for circumcision came in the interpretation of Hafiz al-Din al-Nasfi (d .: $537 \mathrm{AH})$ : (() Or we were tortured until we sent a messenger (and it is not correct for us to afflict some people with a torment rooted in this world only after he has sent them a messenger who makes the case )) [36], and the author of the opinion went and said: ((May God have mercy on him extensively and care for him) do not punish people with severe eradication, which is the torment of the world, except after he sent a messenger to warn them of him and that he should punish him except for his mercy. Mercy is exaggerated, so preaching is the argument after the argument. Punishment is inflicted as the saying of God: oma He tormented us until we sent a messenger ([37] He denied the occurrence of torture not because it is permissible. The verse - as you can see - does not lead to the conclusion of the judgment of reason with the ugliness of punishment without explanation. The punishment of eradication is only after he sends them a messenger and confirms the argument for them and knocks them with the statement after the statement. [38] The apparent meaning of the verse indicates absolutely, and in that case all kinds of joy Father, and reinforces this verse, it says about the torment of the Hereafter: "Kill the regiment, who is storing the pain, you are a harbinger, and he said: Yes, he came to us, and he said an ominous one, so he denied us what God has revealed from him ([39]) And what the times of the general recitation took place in it, it interferes with those who recite [40].

2 - The Almighty's saying: (We have sent a messenger in every nation to worship God the Most High and despair of tyrants.) [41] And the meaning of this verse is that God (the Almighty) did not perish except by mentioning a warning and warning in a legal text. Muhammad bin Jarir al-Tabari (d.310 AH) said: ((The Almighty said: We have sent people to you in every nation, we have presented you with a messenger as we have sent you, to worship God alone without a partner and provide his obedience and obedience. And warn that he will seduce you and prevent you from the path of God, so you will deceive you by inflicting upon them his affliction that does not turn away from him. The people of criminals)) [42]. Sheikh Al-Tusi (d.: $460 \mathrm{AH}$ ) stated in the interpretation of the previous verse: (((God told His Prophet)), may God's prayers and peace be upon him and his family (May God bless him and 
grant him peace), that he sent a messenger in every nation from the previous nations. In order to "associate with God," that is, he commanded them to worship God alone without a partner. Although they avoid worshiping the idol who worships everyone without God. And it was said: The name Satan's idol has the meaning (to avoid) the temptation of Satan, and all farewell calls to corruption.... and delusion - here - that is intended to return from Heaven, and God has called punishment as a delusion. 43] God Almighty has indicated that His Sunnah in His servants is to send messengers to them, and $\mathrm{He}$ has commanded them to worship God and forbade them. He added in the delusion of the stubborn and seductive, like good food, as it benefits and strengthens the natural mood, harms the deviant and removes it, so he said: We have sent in every nation. All that calls for aberration ... and punishment is a delusion, such as saying: "Criminals are astray." Fame [45].

3- Saying of the Almighty :) Messengers, Evangelists and Missionaries: (Glory be to Him, in this verse is the truthfulness of NH. Every argument must be cut off to some extent by sending messengers from missionaries to learn Paradise and vow their stick in Hell. Sheikh Tusi (Tel: $460 \mathrm{AH}$ ) in the interpretation of this verse: And the appreciation of the sending of these prophets sent to the birth of the worshipers missionaries was a substitute from the Attani and the sincerity of the messenger (Omniran) means afraid of my punishment from disobedience and against my command. And the apostles lied so that people would not be an argument against God after the messengers) (46). And Sheikh Al-Tabarsi (d.: 548 AH) said: (They said: Muhammad mentioned him and preferred him by speaking to them, they were sent to Heaven with exhortation and reward for those who believed and obeyed.) And (We remember with fire and the torment of those who disbelieved and disobeyed so that people would not have an argument against God after the messengers): You have not betrayed We have a messenger, and if you were sent, we would have believed in you as the Almighty said to him in another verse by saying: (They said, Our Lord had not sent us a messenger) (47) And Al-Zuhaili said: ((This revelation is from the Qur'an)). The previous heavenly books: It is mercy from God is upon His servants, and from His mercy is that $\mathrm{He}$ does not punish anyone except after a statement, and He does not punish a soul until after the Messenger has been appointed and sent, and after him. Verifying the existence of the mind that is the subject of assignment)) [48]

4-(verses :) Oh book came down to the blessed and followed him, and you fear that you will obtain the mercy that you say. . With what happened. [49] So God Almighty indicated in these verses that $\mathrm{He}$ revealed His book to His Prophet, the Mukhtar Muhammad, may God's prayers be upon him and his family, so that he would not say: The action of the polytheists does not come down to us as a book, so we followed it and we did not enjoin it and did not do it, so there is no excuse for us in that What is the argument of the two sects that were revealed to them The book is before us and they are the Jews and the Jews. The Christians, glory be to God, indicated that the Holy Qur'an was only revealed for an excuse and to remove the problem, so he said that the meaning is said: It is makrooh to say that the book was revealed to a doctrine before us, that is: two groups are the Jews and the Christians, and if you want what I want from us, the book came down to us as it was revealed On them, the Almighty said: He brought you evidence from your Lord, meaning: a clear argument and a clear indication, which is the Qur'an [50]. There are many of its verses that indicate that God Almighty has sent prophets and messengers as preachers with every judgment and event, and this is clear evidence of this legal rule.

\section{The second branch: the indication of the noble Sunnah on the rule: ((There is no crime and no punishment except with a text))}

There are many narrations in the noble Sunnah according to al-Qaeda, and perhaps the most important of these narrations are the following:

1. On the authority of the Prophet Muhammad, may God's prayers and peace be upon him 
and his family and companions, on the authority of Salman al-Farisi: "The Messenger of God, may God's prayers and peace be upon him and his family," He was asked about ghee, cheese and furs, and he said: A in what is permissible, what God has permitted in his book, and what God has forbidden in His book, and is silent about it, so he pardons, and so is the prohibition. Speaking, and being silent about him, he is pardoned, so his silence does not include a hadith on the subject, and he did not prevent him from speaking to him, so he showed that what he kept silent about is neither sin nor punishment, so what is the indication of the rule is clearer.

2. What Ibn Abbas narrated in his narration, he said: ((The people of Jahiliyya used to eat and go out to enter them, so God Almighty sent his Prophet, may God's prayers and peace be upon him and his family and companions. I find what was forbidden to me until the end of the verse)) [52]. This hadith clarifies the meaning of the concept of $\mathrm{Al}$ Qaeda. In order for the act to be permissible, it must contain a legal text, as well as the forbidden act, and thus there is neither penalty nor crime except with legal evidence.

3. Imam Al-Sadiq, may God bless him and grant him peace: (((Everything that is in you, peace and blessings be upon him, is permissible until I know that it has a specific prohibition ... and everything is on this until it appears to others from evidence or drama)) [53]. These two hadiths are clear indications of the principle of neither crime nor punishment except by text.

4. What was narrated on the authority of Abu Al-Darda 'from his narration, he said: (The Messenger of God may God's prayers and peace is upon him and his family and companions, said: God commanded you to do. A duty and an obligation not to do it. You waste it and set limits for you so do not transgress it and deprive you of things so do not transgress it and do not remain silent about things. Without forgetting, do not accuse her of mercy from the Lord, accept it.)) [54] Similarly, Abu Al-Tha'labah's sentiments are similar to the sentiments of the Messenger of God, may God's prayers and peace be upon him and his family and his companions, saying: ((God has imposed obligations, do not limit them, and the limits of the limits do not violate them, and prohibitions, do not deny them. And do not keep quiet about matters as a mercy for you, so do not forget them, so do. Do not search for them.)) [55] The Commander of the Faithful (peace is upon him) narrated on the authority of Ali bin Rabia: Emma M said Ali (peace is upon him). Peace is upon him. These accounts point to conclusive evidence of al-Qaeda's existence. This is because God Almighty has imposed on us our duties, and has commanded us not to waste them, just as He forbade things and commanded us not to go beyond them, otherwise torment will befall us, and we remain silent on what is permissible. Our.

5. Al-Imam Al-Sadiq (peace be upon him): (((Everything that is absolute until the prohibition)) [57]. Evidence of what is needed is clear.

\section{The third branch: the indication of the legal assets of al-Qaeda}

The legal principles can be inferred through scholars' research on the ruling on actions before the mission of the Holy Prophet, may God's prayers and peace be upon him and his family and his companions, in what was not mentioned in a legal text. Is it the origin of adornment or holiness? If the original is jewelry, then the content of the rule proves violating whether authenticity is prohibited. The scholars differed in their research on the principle of principle in matters of three sayings:

\section{First: He who said that the original principle is permissibility}

Tolerance has been achieved among the Imami jurists on the meaning of authenticity in 
permissibility. There is no dispute about it, nor forms of peace with them, so age is upon them. It is no secret to anyone that he may express the ruling on the validity of permissibility and the discrepancy in terms [58]. In Mi'raj Al-Usul it says: ((The inference of the Shari'a on the permissibility, which is two things: the Qur'an and the consensus ... As for the consensus: because the people of the Sharia do not make the mistake of those who initiate something of the suspicions, whether they know the permission in it from the Sharia or it is unknown and does not oblige them to it, and when eating it From eating and drinking he knows the characteristics of its permissibility, and excuses it to many .. If he eats it without knowing it is forbidden, and if it is forbidden, he hastens to commit it until he knows the permission)) [59] this is the view of most of the Hanbalis [60], al-Sanabur [61] and some of the Shafi' is [62]. Those who said that the basic principle is that it is permissible in the Qur'an and Sunnah:

\section{A- From the Holy Quran}

1. (verse:) I created for you in all the earth [63], the speech of all people to the opening verse by saying:) Oh people, worship your Lord ... What is on earth by the grace and grace of God?

2. (Verse :) Say: I do not find what was revealed to the forbidden $((65))$ then the original permissible and the prohibition excluded.

3. And the Almighty says: Say he who forbade [66], for denying the prohibition implies that it is not forbidden, and if the sanctity is lifted, the permissibility is proven [67]

There are many verses in the Qur'an indicating that a person's duty is permissible unless there is evidence from the street that it is crowded, but we are filled with this amount for fear of prolongation.

B - From the pure Sunnah: Those who say that it is permissible quoted several hadiths, including

The legal principles can be inferred through scholars' research on the ruling on actions before the mission of the Holy Prophet, may God's prayers and peace be upon him and his family and his companions, in what was not mentioned in a legal text. Is it the origin of adornment or holiness? If the original is jewelry, then the content of the rule proves a violation if the originality is prohibited. The scholars differed in their research on the principle of assets in three sayings:

\section{First: Whoever said that the principle is permissibility?}

Tolerance has been achieved among the Imami jurists in the sense of authenticity in permissibility. There is no disagreement about that, nor are the forms of peace with them, so the age is upon them. It is no secret to anyone that it is permissible for him to express his ruling on the validity of the passport and its difference [58]. It says in Mi'raj Al-Usul: ((The inference of the Shari'a on the permissibility, namely: the Qur'an and the consensus. As for the consensus: because the people of the Sharia do that. Whoever initiates something of suspicions is not mistaken, whether he knows the permission of it from the Sharia or is unknown and does not oblige him to it. Eating it from eating and drinking knows the characteristics of its permissibility. He excuses many people.. if he ate it without knowing it is forbidden, and if it is forbidden, he should hasten to commit it until he knows the permission)) [59] this is the saying of most of the Hanbalis [60]] and the Sanabur (61) and some Shafi'is [62]. And whoever said: The basic principle is that it is permissible in the Qur'an and Sunnah:

\section{A- From the Holy Quran}

1. (verse :) I created for you in all the earth ([63], the speech of all people in the opening verse by saying:) $O$ people, worship your Lord ... What is on the earth by the grace and grace of God?

2. (verse :) Say: I do not find what was revealed to the forbidden $((65))$, then the original is permissible and the prohibition is excluded.

3. (And the Almighty says: " Say whoever forbade (66), in denying the prohibition indicates that it is not forbidden, and if the 
sanctity is lifted, the permissibility is proven

(67)

There are many verses in the Qur'an which indicate the permissibility of a person's duty, unless there is evidence from the street that it are crowded, but we are so full for fear of prolongation.

\section{Third :Those who say the endowment and their evidence}

The author of the provisions of the Qur'an said in the argument of waqf: "Say that I saw what God has revealed ([79]] in this verse is evidence of what is permissible and forbidden by God Almighty. [80]

\section{Fourth: The chosen saying from these sayings}

He said: The basic principle is that it is permissible: and this is for a number of things, including: Some scholars narrated that there is consensus on this saying, and the strength of its legal evidence. And with this, the ruling is proven after the permissibility is proven.Fourth requirement: applications of the rule of jurisprudence There are three branches of research in this research

\section{The first branch: applications of al-Qaeda in border crimes}

And the most effective rule (no crime and no punishment except by text) lies in the accurate application of Sharia to the content of this rule in hudud crimes, and this is clear from tracking these crimes, and five of them will be dealt with. With:

1. In adultery, the Almighty said: He does not come close to fornication, immorality and evil. ([81] This is the first part (there is no crime and no punishment except by the text), an application of the second part of alQaeda, and in a hadith on the authority of Muhammad bin Qais. The sheikh and the sheikh are one hundred and upon the missionaries.

2. In the crime of defamation, the Almighty said: - Whoever accuses chaste women and then did not bring four martyrs, then they flogged you eighty lashes and did not accept their testimony. Degree.
3. Concerning the crime of drinking alcohol, the Almighty said: " $\mathrm{O}$ he who believes but wine, goodness, statues and slogans, are ugly from the work of Satan. " [85] And in the narration of Ataa ibn Sayara on the authority of al-Baqir, may God's prayers and peace be upon him: (The Messenger of God, may God bless him and grant him peace, said: (God said, may God bless him and his family)) Every intoxicant is wine) [86] These texts and others confirm the prohibition of alcohol and its drinker. And his punishment, as the whipping of the street was limited to that.

4. In the crime of theft, God Almighty says: "The thief and the thief cut off their hands as a reward for their abortion from God, and God Almighty [88], and this text prohibits theft and specifies the punishment.

5. Regarding the crime of banditry, he says: Shame in this world and in the Hereafter is a great punishment for them. ([89] This ruling prohibits thievery and the pursuit of corruption on earth, and determines in this crime death or exile, murder and cutting steel according to its severity and size. In sum, there is no crime in these hudud crimes except forbidden and punishable, Rather, Sharia defined the penalties for hudud crimes and defined them precisely, leaving the judge not free to choose someone else.

\section{Second: Applications of al-Qaeda in crimes of retribution and blood money}

The most effective rule (no crime and no punishment except with a text) in crimes of retribution and blood money lies in the precise application of Islamic law to this rule in this category of crimes, and there is no evidence for this to be included. Among the texts mentioned in these crimes, and the crimes punishable by revenge are: murder Intentional aggression, intentional damage to organs, and intentional wounding. As for the offenses punishable in the first place, they are crimes of retribution if the perpetrator abstains from retribution. Of retribution or refraining from retribution for a 
legitimate reason or legal impediment such as insanity or a minor, then semi-intentional killing, unlawful killing and damaging limbs by mistake and injury Error.

\section{And the crimes punishable}

1 - Killing by aggression: In killing, the Almighty says: Do not kill the soul that God has forbidden except for the truth and killing the oppressed. We have made the guardian not mocked in a murder that was victorious. If a female responds to him from his brother and his followers by offering him kindly, then you're Lord and his mercy will be pleased with him. Then the torment of Allam attacks him. Ibn Lih Al-Hajjaj with said: I heard Ibn Abi Layla say: ((The blood money in the preIslamic era was a hundred camels, and the Messenger of God, may God's prayers be upon him and his family, agreed on it)) [94] And on the authority of Abu Al-Sabah, Al-Kinani narrated on the authority of Abu Abdullah (peace be upon him) s. : ((We asked him as the father of a man who strikes a man with a stick and did not give it up until he died. Is it intended for me to kill him? So he said: Yes, and he leaves it to tamper with, but it is permitted by the sword)) [95], and these texts prohibit premeditated murder, and make his punishment a punishment unless If the guardian of the murdered pardoned his punishment, then the penalty shall be blood. Money is a hundred camels or the equivalent. In semi-intentional killing, blood money is proven. This is evidenced by a hadith on the authority of Abdullah bin Sinan, with his chain of transmission, he said: ((I heard Abu Abdullah Peace be upon him says: The Commander of the Faithful, may God's prayers and peace be upon him, said: An almost intentional mistake that is killed with a whip, stick, or stones: This blood money is getting thicker, and it is a hundred camels ... and the mistake is thirty fair girls, thirty girls. Bonn, twenty girls in labor, and twenty of Labon's sons, male)) [96]. This text prohibits semi-premeditated murder and is punishable by bediya. Likewise, in vain murder, the Almighty said: (As for the believer to kill a believer by mistake, and whoever kills a believer by mistake, the believer is the believer and the believer is a slave. [97]) these two provisions forbid wrongful killing and they are punished with a Bediya.

2 -Intentionally sabotaging the limbs: In the crime of deliberately sabotaging and deliberately injuring the limbs, the Almighty says: (You have life in the novel, $\mathrm{O}$ most children, until you fear [98]) And God Almighty says: And if you are punished, then you are punished in the same way as you were punished, and because your patience is good For the sick. [99] The Almighty says: We wrote to them self-respect, an eye for an eye, a nose, an ear, a nose, an ear, a tooth for a tooth and wounds as a result of what he thinks. They are atonement for him, and those who did not make up for what God has revealed are their fast ([100]), and the Almighty says: (And if you do punish, He will punish you, because your patience is better for the servant. He said: He said: It is... like premeditated murder and surgery where retribution is wrong, murder and blood money surgery is wrong. "(102) These texts are explicit in prohibiting the loss of organs and wounds, and the punishment in the case of intentional retribution and blood money in the case of error, and it is clear from the above that c- a crime Retribution and parental punishment came in the Islamic Shari'a defined by actions. Islamic Sharia has explicitly stipulated these penalties in a way that does not leave even the judge with the freedom to choose or estimate the punishment, and every duty he has to inflict the prescribed punishment if it is proven to him that the perpetrator is the perpetrator.

\section{Third: the applications of al- Qaeda in discretionary crimes}

The effect of this rule on discretionary crimes is evident through the strict application of Islamic law on the basis of neither crime nor punishment except by a stipulation in discretionary crimes and discretionary crimes. They are crimes for which no punishment was stipulated in the Qur'an and Sunnah. Rather, the matter of estimating them was left to the guardian in light of the public interest and the scale of the crime, but Sharia did not apply this rule. In the way it is applied in hudud 
crimes, or crimes of retribution and parentage, and he did not adhere to the narrow limits that he restricted in applying the rule to those crimes, but Sharia expanded the application of the rule to crimes of retribution and blood money. Consolation to some extent. For the general interest and nature require this expansion. Discretionary crimes are among the crimes specified in the Holy Qur'an and the Sunnah of the Prophet, and their punishment has not been specified.

1. The crime of espionage stipulated in the verse (and espionage) [103].

2. The crime of false testimony stipulated in the Almighty's saying: Avoiding the abomination of idols and avoiding speaking lies [104], and crimes of hadd punishment or retribution whose conditions are not fulfilled as a crime of adultery if not proven. Acknowledgment of four witnesses and the crime of theft if the money does not reach the quorum, and the crime of murder if the guardian waives the qisas by blood. Each such crime does not apply to it the specified penalty, but the penalty of ta'zir is estimated by the father's order.

\section{Conclusion}

It is clear from what we have said that Islamic Sharia has advanced the revenues with texts that affirm the rule (not a crime and not only a text of punishment). In the provisions of public law, he enjoins justice and charity and forbids injustice only, but it is based on specific and explicit texts in this sense, as in the Almighty saying: (We are punishment until we send a messenger). [105] And it is clear from this noble verse that there is no crime and no punishment unless someone warns that God punished people for their rulings before sending the messengers. Likewise the narrations of verses and many narrations rooted in that rule, such as narrated on the authority of Ali ibn Rabi'a to the Commander of the Faithful. About things and he did not forget them, so do not take them for granted)) [106] and likewise the inference of the legal basis (the principle in permissible) for establishing the rule according to Sharia.

\section{The most important of the results in this rule were reflected in two things}

The first thing: there is no retroactive effect of the texts of the crime, meaning that criminalization is a warning to individuals of what is forbidden to them. The warning is not only for the future, and in this came the verse: (Let it be a gift and God will revenge it against it), and this is what is known today as the rule of non-retroactivity of the provisions of incrimination, i.e. the law. The second matter: adherence to the statement in the criminalization texts: meaning that the holy law must be clear in the criminalization of both parts that is, counting the act of the crime and determining the punishment for it - it is not sufficient for the Holy Street to limit the acts that it considers crimes. But you must know every crime and explain its components and conditions, as it moves away from ambiguity and denies ignorance. In the case of referring on the other hand to the penalty that has been specified for it, taking into account in this statement the definition of its nature or type, its amount, or how it is estimated Because it is incorrect, in terms of punishment for an act or action, unless it contains all the elements that make it applicable to describing what is stipulated in the sacred law. Hence, it is not a criminal offense and E. No E. Known is punishable under a legal provision issued prior to the commission of the act, and is not enforceable retroactively; because the original in LASH J passport is useful.

\section{References}

\section{The Holy Quran}

1. August $n$ the Arab al- Maliki, Mohammed bin Abdullah (v. N: $1424=2003$ ), the provisions of the Koran ,i 3 ,see its origins and came out his speeches and commented upon by : Mohamed Abdel Kader Atta ,Beirut :Dar scientific books.

2. Abn Faris, Ahmad (T.N .: 1404 AH), Dictionary of Language Standards 1 ,st Edition, Qom :Islamic Information Office. 
3. Ibn Manzur, Muhammad Ibn Makram (T. N $\therefore \quad 1414$ AH), Lisan al-Arab3,rd Edition ,Beirut :Dar Sader.

4. Abu Al-stay Al-Kafawi, Ayoub Bin Musa ) T.N 1419 :. A.H. = 1989 A.D , (.Al-Kuliyat, 2nd edition, under: Adnan Al-Darwish - Muhammad AlMasry ,Beirut :Foundation for the message.

5. Abu Dawud, Suleiman bin Al-Ash'ath AlSijistani (d. N: 1410 A.H. = 1990 A.D.), Sunan Abi Dawood, ed,1 .ed: Saeed Muhammad Al-Lahham,Beirut :Dar AlFikr for printing, publishing and distribution.

6. Abu Zahra, Muhammad Ahmad Mustafa Ahmed) T.N 1966 :. A.D , (.Crime and Punishment in Islamic Jurisprudence Crime - Egypt: The House of Arab Thought.

7. Andalusian, Muhammad bin Yusuf bin Ali (T.N .: $1422 \mathrm{AH}=2001 \mathrm{CE}$ ), Tafsir al-Bahr al-Muhit, under: Sheikh Adel Ahmad Abd al-Muawwad - Sheikh Ali Muhammad Muawad ,Beirut :Dar al-Kutub al-Ilmiyya

8. Al-Bukhari, Muhammad bin Ismail (d. $\mathrm{N}$.: 1410 AH, (Sahih Al-Bukhari, ed ,2 . Tah: Egypt .Ministry of Endowments .Supreme Council for Islamic Affairs .Committee for the Revival of Sunnah Books, Cairo : Ministry of Endowments, Supreme Council for Islamic Affairs, Committee for Reviving Sunnah Books.

9. Albrkia, Mohammad Amim charity (v. N: $1424=2003), \quad$ the definitions of jurisprudence ,i 1 ,Baghdad :Dar scientific books.

10. Al-Thanawi, Muhammad Bin Ali Ibn AlQadi Muhammad Al-Hanafi (T.N .: 1996 AD), Encyclopedia of Scouts of Art and Science Terminology1, st Edition, ed: Dr.Ali Dahroug, Beirut :Lebanon Library Publishers.

11. Al-Jarjani, Ali bin Muhammad bin Ali AlZain (d. N: 1403 AH = 1983 AD), definitions, corrected and corrected by a group of scholars, 1st Edition, Beirut :Dar Al-Kutub Al-Ilmiyya.
12. Al-Khoei, Abu Al-Qasim, Misbah Al-Usul (T.N 1420 :. A.H, (.ed ,6 .Qom: AlAlamiya, Al-Dawri Library.

13. Al-Daraqutni, Ali bin Omar bin Ahmed (T.N : 1417 AH = 1996 CE), Sunan alDaraqutni, U: Majdi bin Mansour Syed alShura, Edition 1 ,Beirut :Dar al-Kutub alIlmiyya.

14. Al-Razi, Muhammad bin Omar bin AlHassan (d. N: 1421 AH = 2000 AD), Miftahs of the Unseen, Beirut :Dar AlKutub Al-Ilmiyya.

15. Al-Zubaidi, Mortada bin Muhammad bin Muhammad (d. N: 1414 AH), Taj AlArous1 ,st Edition, Beirut :Dar Al-Fikr.

16. Al-Zuhaili, Wehbe bin Mustafa, Al-Tafsir Al-Wasit) TN: 1427 AH = 2006 AD, ( ed. 2 ,Publisher :Beirut :House of Contemporary Thought.

17. Al-Zarkashi, Badr Al-Din Muhammad Bin Bahar)d. N .: 1421 AH), Al-Bahr Al-Bahr in Usul Al-Fiqh, Controlled by: Dr .Muhammad Omar1 st floor ,Beirut :Scientific Books Library.

18. Al-Samaani, Mansour bin Muhammad bin Abdul-Jabbar (d. N: 1418 AH $1999=$ AD), Segments of Evidence in Usull ,st Edition, Under: Muhammad Husayn Muhammad al-Shafei,Beirut :Dar al-Kutub al-'Ilmiyya.

19. Al-Sharif Al-Radhi, Muhammad bin AlHussein (T.N :: 1414 A.H.), Nahj AlBalaghah, under: Subhi Al-Saleh, Qom :Dar Al-Hijrah Foundation.

20. Al-Shawkani, Muhammad bin Ali bin Muhammad (d. N.: 1356 AH), Guiding the Stallions to Realize the Truth from the Science of Usull ,st Edition ,Egypt :Mustafa Al-Babi Al-Halabi and Sons Press.

21. Sheikh Shirazi, Naser Makarem, in the interpretation of the Book of the perfect God 's house) v. N: 1421 , (i 1 , then :publications School of Imam Ali bin Abi Talib (AS. (

22. Al-Saduq, Muhammad bin Ali bin AlHussein (d. N.: 1404 AH), who does not 
attend the Faqih, ed, 2 .Qom :Islamic Publishing Foundation.

23. Al-Tabataba'ei, Sayyid Muhammad Husayn (d. N 1417 :AH , (Al-Meezan fi Tafsir alQur'an5, th Edition, Qom :Islamic Publishing Institution affiliated with the Teachers Group.

24. Al-Tabarani, Suleiman bin Ahmed (T.N :. 1415 A.H. = 1995 A.D.), Al-Mujam AlAwsat, under: Investigation Department, Dar Al-Haramain ,Cairo :Dar Al-Haramain for printing, publishing and distribution.

25. Al-Tabarsi, Al-Fadl Bin Al-Hassan (T.N .: 1415 A.H. = 1995 A.D.), Collective AlBayan in Interpretation of the Qur'an, edited and commented: A Committee of Scholars and Specialized Investigators, First Edition, Beirut :Al-Alamy Foundation for Publications.

26. Al-Tabari, Muhammad bin Jarir (T.N .: 1415 A.H. = 1995 A.D.), Jami al-Bayan on the interpretation of the verse of the Qur'an, translated and presented by: Sheikh Khalil Al-Mays , control, documentation and production: Sadqi Jamil AlAttar ,Beirut :Dar Al-Fikr for printing, publishing and distribution.

27. Al-Tahtawi, Ahmed bin Muhammad bin Ismail (d. N: 1438 AH = 2017 CE), AlTahtawi's commentary on al-Dur alMukhtar Sharh Tanweer al-Ibsar, under: Sheikh Ahmad Farid al-Mazidi, First Edition, Beirut :Dar al-Kutub al -Ilmiyya.

28. Al-Tarihi, Fakhr Al-Din Bin Muhammad (d. $\mathrm{N}: \quad 1417 \quad$ AH), $\quad$ Bahrain Mall3 ,rd floor, Tehran: Al -Murtazawi.

29. Al-Tusi, Muhammad ibn Al-Hassan (T.N .: 1365 AH), Tahdheeb Al-Ahkam, under: AlSayed Hassan Al-Musawi AlKhurasan4, th Edition, Tehran :Dar AlKotob Al-Islamiyyah , the printing press: Khorshid.

30. Al-Tusi, Muhammad bin Al-Hasan (T.N .: 1409 AH), Al-Tebyaan fi Tafsir AlQur'an, First Edition, Qom :Islamic Information Office.
31. Al-Toufi, Suleiman bin Abd al-Qawi bin Abd al-Karim (T.N 1407 :. AH = 1987 CE, a brief explanation of al-Rawda, ed .Abdullah Al-Turki1 ,st floor ,Beirut :The Message Foundation.

32. Return, Abdul Qadir ,the Islamic criminal legislation comparative positive law, Beirut :Dar Arab writer.

33. Al-Ghazali, Muhammad bin Muhammad (T.N .: 1413 AH $1993=$ AD), Al-Mistasfa from the science of origins, under: Muhammad Abd al-Salam Abd al-Shafi, First Edition, Beirut: Dar al-Kutub alIlmiyya.

34. Fur Hambali, Mohammed bin Hussein bin Mohammed (v. N: 1410), in preparing the principles of jurisprudence, the Open: Sir Mubarak j , i 2 , a University of King Mohammed Bin Saud Islamic University, College of Sharia.

35. Al-Farahidi, Al-Khalil bin Ahmed, (T.N .: $1409 \quad$ AH), Kitab Al-Ain, ed. 2 ,Qom :publishing the migration.

36. Al-Qazwini, Muhammad Ibn Yazid, known as Ibn Majah $(1430=2009$ AD), Sunan Ibn Majah, U: Shuaib Al-Arna`ut - Adel Murshid - Muhammad Kamil Karah Belli Abd al-Latif Harz Allah1,st edition ,Beirut :Dar Al-Risalah Al-Ilmiyya.

37. Al-Kashani, Fathallah bin Shukrallah (T.N : 1423 A.H.), The Butter of Interpretations, Under: The Foundation for acquaintance, Qom :The Islamic Knowledge Foundation, Atert Press.

38. Al-Kulayni, Muhammad bin Ya'qub bin Ishaq (T.N :. 1434 AH), Al-Kafi, chan: Department of Heritage Revival3 , rd Edition, Qom :Dar Al-Hadith for Printing and Publishing.

39. Al-Mawardi, Ali bin Muhammad bin Muhammad (d. N: 1427 AH = 2006 AD), Al-Ahkam Al-Sultani, Under: Ahmed Gad ,Cairo :Dar Al-Hadith.

40. Detective ornaments, Jaafar bin Hassan bin jh j j) v. N: 1403 ,(Qubool assets, i 1 , then :Al - Bayt Foundation (peace 
be upon them) for printing and publishing, the master of martyrs (peace be upon him) Press.

41. Al-Mostafawi, Sayyid Muhammad Kazim, One Hundred Jurisprudence Base ) TN 1417 : AH3 , (rd Edition, Qom :The Islamic Publishing Institution of the Teachers Group.

42. An-Naqi, Muhammad Mahdi bin Abi Dharr (T.N: $1422 \mathrm{AH}$ ), University of Usul U: Rida Al -Astadi, 1st Edition, Qom :Salman Al-Farsi.

43. Al-Nassfi, Abdullah bin Ahmed bin Mahmoud (T.N.: 2005 CE,(Perceptions of tanzil and the facts of interpretation (Tafsir al-Nasfi, (Under Marwan Muhammad alShaar ,Beirut :Dar al-Nafaes.

\section{Margins}

1. Prisoners: 15 .

2. An-Nahl: 79.

3. An-Nahl: 89.

4. See: Ahmad Ibn Faris (T: 395 AH), Dictionary of Maqayas Linguistics, 5 / 108-109.

5. The Cow: 127.

6. Ibn Manzur, Muhammad bin Makram (T: 711 AH) 3/361.

7. See: Al-Taraihi, Fakhr Al-Din Bin Muhammad (T .: 1085 AH), Bahrain Mall, 3/129.

8. Al-Jarjani, Ali Bin Muhammad (T: 816 AH), Tariffs, 171.

9. The residency of Abu Al-Koufa, Ayoub bin Mus Zed (Tel: 1094 AH), Colleges 0.728 .

10. Al-Thanawi, Muhammad bin Ali AlHanafi (T: 1158 AH), Encyclopedia of Conferences for Scouts of Art and Science, 2/1295.[11] See: Al-Farahidi, Al-Khalil bin Ahmed, (T: $175 \mathrm{AH}), 6$ / 118-119.

11. See: Ibn Manzur, Muhammad Ibn Makram, Lisan al-Arab, 12/92.

12. Al-Ma`idah: 2.
13. Look: Al-Zubaidi, Mortada Bin Muhammad Bin Muhammad (1205 AH), Taj Al-Arous, 10/16.

14. See: previous source, 10/16.

15. Al Mawardi Ali Bin Muhammad Bin Muhammad (d: 450 AH) Al-Ahkam AsSultani 322.

16. Odeh, Abd al-Qadir, on Islamic criminal legislation compared to positive law, 1/66.

17. Abu Zahra, Muhammad Ahmad Mustafa Ahmed, Crime and Punishment in Islamic Jurisprudence - Crime, 22.

18. See: ibid., 22.

19. Ibn Manzur, Muhammad bin Makram Lisan al-Arab, 1/611.

20. Ibn Faris, Ahmad (d $\quad . \quad 395$ AH), Dictionary of Maqayas Linguistics, 4/77.

21. Al-Mawardi, Ali bin Muhammad bin Muhammad, Al-Ahkam As-Sultani, 325.

22. Al-Tahtawi, Ahmad bin Muhammad bin Ismail (T: $1231 \mathrm{AH}$ ) Sharh Al-Tahtawi on Al-Dur Al-Mukhtar, 3/6.

23. Odeh, Abd al-Qadir, Islamic criminal legislation compared to positive law, 609/1.

24. Ibn Manzur, Muhammad Ibn Makram (T: 711 AH) by Lisan al-Arab 7/97.

25. Al-Zubaidi, Mortada bin Muhammad bin Muhammad (1205 AH), Taj Al-Arous, 9/370.

26. See: Al-Ghazali, Muhammad bin Muhammad (d: 505 AH), Al-Masa'a min Uloom Al-Usul, 3 / 84-85.

27. See: Al-Barakti, Muhammad Amim alIhsan (T: $1395 \mathrm{AH}$ ), Definitions of Fiqh, 228.

28. Al-Israa: 15.

29. Al-Tusi, Muhammad Ibn Al-Hassan (d: $460 \mathrm{AH})$, Al-Tebeen fi Tafsir Al-Qur'an, 6 / 457-458.

30. Captain Muhammad Mahdi bin Abi Dhar (d: 1209 AH) Osoul University, 32-33.

31. Al-Isra: 15.

32. Views: Al-Razi, Muhammad bin Omar bin Al-Hassan (d: 606 AH), 27/65. 
33. See: Sheikh Al-Shirazi, Nasir Makarem, Al-Awthal in Interpretation, The Book of God Almighty, 8 / 428-429.

34. See: Andalusian, Muhammad bin Yusuf bin Ali (d: 745 AH), al-Bahr al-Bahr alBahr al-Maher 6/15.

35. Al-Nasfi, Abdullah bin Ahmed bin Mahmoud (d: $710 \mathrm{AH}$ ), perceptions of submission and facts of interpretation, $2 / 257$

36. Al-Israa: 15.

37. Al-Tabatabai, Sayyid Muhammad Husayn (d: 1402 AH), Al-Meezan fi Tafsir alQur'an, 13/58.

38. King: 8-9.

39. See: Andalusian, Muhammad bin Yusuf bin Ali bin Yusuf, interpretation of the ocean ocean, 6/15.

40. An-Nahl: 36.

41. Al-Tabari, Muhammad bin Jarir (d: 310 AH), Jami al-Bayan fi Tafsir of the verse of the Qur'an, 14/138.

42. Al-Tusi, Muhammad ibn Al-Hassan, the two subordinates in the interpretation of the Qur'an 6/379.

43. Al-Razi, Muhammad bin Umar bin AlHassan, Keys to the Unseen, 20/27.

44. Al-Kashani Fathallah bin Shukrallah (T: 988 AH) 3 / 562-563.

45. Al-Tusi, Muhammad Ibn Al-Hasan, AlTaban fi Tafsir Al-Qur'an 3/394.

46. Al-Tabarsi, Al-Fadl Bin Al-Hassan (T: 548 AH), Majma' al-Bayan fi Tafsir alQur'an, 3 / 242-243.

47. Al-Zahili and Wahba bin Mustafa, AlTafsir Al-Wasit 3/1923

48. Al-An'am: 155-157.

49. See: Sheikh Al-Tabarsi, Al-Fadl bin AlHassan, Majma 'Al-Bayan, 4 / 199-200.

50. Al- Qazwini, Muhammad bin Yazid, known as Ibn Majah (d : $273 \mathrm{AH}$ ), Sunan Ibn Majah.459/4,

51. Father and Dawood, Sulaiman bin AlAsh'ath Al-Sijistani (d .: 275 AH), Sunan Abi Dawood .208/2,
52. Al - Kulayni, Muhammad bin Ya'qub bin Ishaq (T .: 329 AH), Al-Kafi .542/10,

53. Al - Tabarani, Suleiman bin Ahmed (d .: 360 AH), Al -Mujam Al -Awsat.381/8,

54. Al -Daraqutni, Ali bin Omar bin Ahmed (d $\therefore 385$ AH), Sunan al-Daraqutni .109/4,

55. Sharif Al-Radhi, Muhammad bin AlHussein (d $\therefore 406$ AH), Nahj AlBalaghah. 487 ,

56. Al-Saduq, Muhammad bin Ali bin AlHussein (d :: $381 \mathrm{AH})$, Whoever Al-Faqih does not attend.317/1,

57. Al-Mostafawi, Sayyid Muhammad Kazim, One Hundred Jurisprudence Principles.124,

58. The investigator ornaments, Jaafar bin Hassan bin j h j j) t: 676 e), Qubool assets.206-205,

59. See :Al -Fur 'Al-Hanbali, Muhammad Ibn Al-Hussein Bin Muhammad (d .: 526 AH), Al-iddah fi Usul Al-Fiqh.1241/4 ,

60. Al - Toufi, Sulaiman bin Abdul Qawi bin Abdul Karim (T .: $716 \mathrm{AH}$ ), a brief explanation of al-Rawda.391/1,

61. See :Al-Samaani, Mansour bin Muhammad bin Abdul-Jabbar (d .: 489 $\mathrm{AH}$, ,Segments of Evidence in AlUsul.48/2,

62. The Cow: 29.

63. The Cow: 21.

64. Al-An'am: 145.

65. Al-A'raf: 32.

66. See: Al-Razi, Muhammad bin Omar bin Al-Hassan, Keys to the Unseen, 10/14.

67. Al-Kulayni, Muhammad bin Ya'qub bin Ishaq, Al Kafi .542/10,

68. The previous source.541/10,

69. Al-Khoei, Abu Al-Qasim, Misbah AlUsul.274/2,

70. Al - Qazwini, Muhammad bin Yazid, known as Ibn Majah (d .: $273 \mathrm{AH}$ ), Sunan Ibn Majah.459/4 ,

71. See: Al-Zarkashi, Badr Al-Din Muhammad Bin Bahar (d .: 794 AH), AlBahr Al-Bahr fi Usul Al-Fiqh.121/1,

72. Source of the former. 
73. Source of the former.

74. Al-Ma'idah: 120.

75. An-Nahl: 116.

76. See: Al-Shawkani, Muhammad bin Ali bin Muhammad (d: 1250 AH), Guiding the stallions to achieve the truth from the science of assets. 285

77. Ibid

78. Yunus: 39.

79. August N .Arab al - Maliki, Mohammed bin Abdullah (Tel: 543 e.11/3,

80. Al-Israa: 32.

81. The Light: 2.

82. Al - Kulayni, Muhammad bin Ya'qub bin Ishaq, Al-Kafi, 14/18.

83. The Light: 4.

84. Al-Ma'idah: 90.

85. Al - Kulayni, Muhammad bin Ya'qub bin Ishaq, Al-Kafi, 12/706.

86. Ibid.118/14

87. Al-Ma'idah: 38.

88. Al-Ma'idah: 33.

89. See: Odeh, Abd al-Qadir, Islamic criminal legislation compared to positive law, $1 / 121$.

90. Al-Israa: 33.

91. The Cow: 178.

92. Al - Bukhari, Muhammad bin Ismail (T .: $256 \mathrm{AH},($ Sahih Al-Bukhari.309/10,

93. Al-Kulayni, Muhammad bin Ya'qub bin Ishaq, Al-Kafi, 14/301.

94. source of the former.279/7,

95. source of the former.303/14,

96. An-Nisa ': 92.

97. The Cow: 179.

98. An-Nahl: 126.

99. Al-Ma'idah: 45.

100. An-Nahl: 126.

101. Al- Tusi, Muhammad ibn AlHasan (460 AH), Tahdheeb AlAhkam.174/10,

102. The rooms: 12 .

103. Hajj: 30.

104. Al-Israa: 15.

105. Sharif Al-Radhi, Muhammad bin Al-Hussein, Nahj Al-Balaghah, 487. 